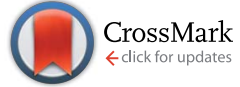

Cite this: J. Mater. Chem. B, 2014, 2, 6412

Received 25th May 2014

Accepted 23rd July 2014

DOI: $10.1039 / c 4 t b 00850 b$

www.rsc.org/MaterialsB

\section{Folic acid modified clay/polymer nanocomposites for selective cell adhesion $\dagger$}

\begin{abstract}
F. B. Barlas, ${ }^{a}$ D. Ag Seleci, ${ }^{a}$ M. Ozkan, ${ }^{b}$ B. Demir, ${ }^{a}$ M. Seleci, ${ }^{a}$ M. Aydin, ${ }^{c}$
M. A. Tasdelen, ${ }^{\text {cd }}$ H. M. Zareie, ${ }^{\text {ef }}$ S. Timur, ${ }^{\text {aag }}$ S. Ozcelik ${ }^{b}$ and Y. Yagci ${ }^{\star c h}$

A folic acid (FA) modified poly(epsilon-caprolactone)/clay nanocomposite (PCL/MMT- $\left.\left(\mathrm{CH}_{2} \mathrm{CH}_{2} \mathrm{OH}\right)_{2}-\mathrm{FA}\right)$ resulting in selective cell adhesion and proliferation was synthesized and characterized as a cell culture and biosensing platform. For this purpose, first the $\mathrm{FA}$ modified clay $\left(\mathrm{MMT}-\left(\mathrm{CH}_{2} \mathrm{CH}_{2} \mathrm{OH}\right)_{2}-\mathrm{FA}\right)$ was prepared by treating the organo-modified clay, Cloisite $30 \mathrm{~B}\left[\mathrm{MMT}-\left(\mathrm{CH}_{2} \mathrm{CH}_{2} \mathrm{OH}\right)_{2}\right]$ with FA in chloroform at $60{ }^{\circ} \mathrm{C}$. Subsequent ring opening polymerization of $\varepsilon$-caprolactone in the presence of tin octoate ( $\left.\mathrm{Sn}(\mathrm{Oct})_{2}\right)$ using MMT- $\left(\mathrm{CH}_{2} \mathrm{CH}_{2} \mathrm{OH}\right)_{2}-\mathrm{FA}$ at $110{ }^{\circ} \mathrm{C}$ resulted in the formation of MMT- $\left(\mathrm{CH}_{2} \mathrm{CH}_{2} \mathrm{OH}\right)_{2}-\mathrm{FA}$ with an exfoliated clay structure. The structures of intermediates and the final nanocomposite were investigated in detail by FT-IR spectral analysis and DSC, TGA, XRD, SEM and AFM measurements. The combination of FA, PCL and clay provides a simple and versatile route to surfaces that allows controlled and selective cell adhesion and proliferation. FA receptor-positive HeLa and negative A549 cells were used to prove the selectivity of the modified surfaces. Both microscopy and electrochemical sensing techniques were applied to show the differences in cell adherence on the modified and pristine clay platforms. This approach is expected to be adapted into various bio-applications such as 'cell culture on chip', biosensors and design of tools for targeted diagnosis or therapy.
\end{abstract}

\section{Introduction}

Poly(epsilon-caprolactone)/clay (PCL/clay) nanocomposites have attracted much attention due to the biocompatibility and biodegradability of the aliphatic polyester matrix and high property enhancements that could result from the layered silicate dispersion. ${ }^{1,2}$ There are three common approaches for the preparation of these nanocomposites: in situ polymerization, solution casting, and melt processing, which are known to lead to intercalated and/or exfoliated structures. ${ }^{3}$ Recently, several coupling reactions were also proposed as an alternative route to

${ }^{a}$ Department of Biochemistry, Faculty of Science, Ege University, 35100 Bornova, Izmir, Turkey.E-mail: suna.timur@ege.edu.tr

${ }^{b}$ Department of Chemistry, Faculty of Science, Izmir Institute of Technology, 35430 Urla, Izmir, Turkey

${ }^{c}$ Department of Chemistry, Istanbul Technical University, Maslak, Istanbul 34469, Turkey

${ }^{d}$ Department of Polymer Engineering, Faculty of Engineering, Yalova University, 77100 Yalova, Turkey

${ }^{e}$ Department of Materials Science and Engineering, Izmir Institute of Technology, 35430 Urla, Izmir, Turkey

Institute for Nanoscale Technology, University of Technology, Sydney, Australia

${ }^{g}$ Ege University, Institute of Drug Abuse Toxicology \& Pharmaceutical Sciences, 35100Bornova, Izmir, Turkey

${ }^{h}$ Center of Excellence for Advanced Materials Research (CEAMR), Department of Chemistry, Faculty of Science, King Abdulaziz University, 21589, Jeddah, Saudi Arabia $\dagger$ Electronic supplementary information (ESI) available. See DOI: 10.1039/c4tb00850b fabricate such clay based nanocomposites having various structurally different macromolecular chains. ${ }^{4-9}$ In the in situ polymerization technique, epsilon-caprolactone (CL) as a monomer, together with an alcohol functional initiator with stannous octanoate $\left(\mathrm{Sn}(\mathrm{Oct})_{2}\right)$ as a catalyst, is intercalated within the silicate layers and polymerization is initiated by heating the mixture at $110{ }^{\circ} \mathrm{C} .{ }^{9}$ The chain growth in the clay galleries triggers the clay exfoliation and hence the nanocomposite formation. ${ }^{\mathbf{1 0 - 1 8}}$

In biomedical research, cultivation of cells on a substratum is one of the most crucial experimental procedures and extensively used in bio-investigations. In order to utilize polymer-clay nanocomposites, they should have designed mechanical properties as well as favourable interactions with biological interfaces. ${ }^{19}$ The cultivation of various kinds of cells was carried out to investigate embryology, cytology, and tissue regeneration on scaffolds or to assess biocompatibility and in vitro toxicity of newly developed drug candidates, medical devices, as well as materials. For instance, in vitro cytocompatibility of laponite cross-linked poly(ethylene oxide) hydrogel films using MC3T3E1 mouse pre-osteoblast cells was reported. ${ }^{19}$ In the other study, thermo-sensitive poly( $N$-isopropyl acrylamide) nanocomposite gels were used as a soft and wet surface material with the capability of thermally controlled cell adhesion and detachment without the need for proteolytic enzyme treatment. ${ }^{20}$ Cell adhesion and spreading on porous poly(lactic acid)-montmorillonite nanocomposites and clay-gelatin-chitosan nanocomposite 
films were also investigated in the literature. ${ }^{21,22}$ On the other hand, controlling and guiding cell adhesion on biomaterials are important for a variety of bio-applications. Biocompatibility can be improved by limiting non-specific adsorption of proteins and promoting specific cell-matrix interactions which are important due to their effects on regulation of cell function, tissue homeostasis and cell shape. ${ }^{23-26}$

Recently, folic acid (FA) intercalated montmorillonite (MMT) was successfully used as a targeted surface for cell culture applications to discriminate the adhesion of folate receptor positive and negative cell lines. ${ }^{27}$ The FA modified clay not only enhanced specificity for cell adhesion, but also exhibited unique properties such as good mechanical and chemical stabilities, high surface area and low toxicity. We describe here, FA modified PCL/clay nanocomposites as a non-toxic cell adhesion material for various bio-investigations such as selective cell biosensing.

\section{Experimental}

\section{Materials}

An organo-modified clay, Cloisite 30B [MMT- $\left.\left(\mathrm{CH}_{2} \mathrm{CH}_{2} \mathrm{OH}\right)_{2}\right]$ was purchased from Southern Clay Products (Gonzales, TX, USA). The organic content of organo-modified MMT, determined by thermogravimetric analysis (TGA), was $21 \mathrm{wt} \%$. Before use, the clay was dried under vacuum at $110{ }^{\circ} \mathrm{C}$ for $1 \mathrm{~h}$. Tin(II) 2-ethyl-hexanoate $\left(\mathrm{Sn}(\mathrm{Oct})_{2}\right.$, Aldrich, 95\%) and folic acid (FA, Aldrich, 97\%) were used as received. Epsilon-caprolactone (CL, Aldrich, 97\%) was vacuum distilled over calcium hydride. Commercial grade solvents were purified by conventional drying and distillation procedures. Phosphate buffered saline (PBS, pH 7.4), 3-(4,5-dimethylthiazol-2-yl)-2,5-diphenyl tetrazolium bromide (MTT), 4,6-diamino-2-phenylindol (DAPI), tetrahydrofuran (THF), sodium dodecyl sulphate (SDS), formaldehyde and bovine serum albumin (BSA) were purchased from Sigma. Cell culture supplies including Dulbecco's Modified Eagle Medium (DMEM), fetal calf serum (FCS Gold) and penicillin/streptomycin $(\mathrm{P} / \mathrm{S}, 100 \times)$ were purchased from Lonza (Basel, Switzerland).

\section{Modification of MMT- $\left(\mathrm{CH}_{2} \mathrm{CH}_{2} \mathrm{OH}\right)_{2}$ with FA}

MMT- $\left(\mathrm{CH}_{2} \mathrm{CH}_{2} \mathrm{OH}\right)_{2}, 176 \mathrm{mg}, 0.1 \mathrm{mmol}$, OH-content and FA ( $88 \mathrm{mg}, 0.2 \mathrm{mmol}$ ) were added in $50 \mathrm{~mL}$ chloroform. The reaction mixture was heated up to $60{ }^{\circ} \mathrm{C}$ and stirred for $48 \mathrm{~h}$. After cooling to room temperature and removing the solvent by filtration, modified MMT (MMT- $\left.\left(\mathrm{CH}_{2} \mathrm{CH}_{2} \mathrm{OH}\right)_{2}-\mathrm{FA}\right)$ was washed with chloroform and water three times and finally dried under vacuum.

\section{Synthesis of poly( $\varepsilon$-caprolactone)/MMT (PCL/MMT) nanocomposites containing $\mathrm{FA}$}

(MMT-(CH2CH2OH)2-FA) (20 mg, $0.17 \mathrm{mmol}$ corresponding to $1.0 \%$ of the monomer by weight) as the initiator was added in Schlenk tubes equipped with a magnetic stirrer and dried in an oil bath at $90{ }^{\circ} \mathrm{C}$ for $1 \mathrm{~h}$ with a vacuum pump. $1.94 \mathrm{~mL}(2.0 \mathrm{~g}$, $17 \mathrm{mmol}$ ) sample of monomer (CL), [Sn(Oct) $\left.)_{2}\right]$ (1/300 molar ratio with respect to monomer) and $2.0 \mathrm{~mL}$ of dry toluene were added under nitrogen. The CL polymerization reactions were carried out at $110{ }^{\circ} \mathrm{C}$. After $24 \mathrm{~h}$ the mixtures were diluted with THF and poured into a 10 -fold excess of cold methanol. The products were collected after filtration and dried at room temperature in a vacuum. Composites with higher clay contents were prepared under similar experimental conditions.

\section{Characterization}

Fourier transform infrared (FT-IR) spectra were recorded on a Perkin-Elmer FT-IR Spectrum One B spectrometer. Molecular weights were determined by gel permeation chromatography (GPC) using an instrument consisting of a Viscotek GPCmax Autosampler, a pump, three ViscoGEL GPC columns $\left(\mathrm{G} 2000 \mathrm{H}_{\mathrm{HR}}, \mathrm{G} 3000 \mathrm{H}_{\mathrm{HR}}\right.$ and $\left.\mathrm{G} 4000 \mathrm{H}_{\mathrm{HR}}\right)$, and a Viscotek differential refractive index (RI) detector with a THF flow rate of $1.0 \mathrm{~mL} \mathrm{~min}^{-1}$ at $30{ }^{\circ} \mathrm{C}$. The RI detector was calibrated with polystyrene standards having narrow molecular weight distribution. Data were analyzed using Viscotek OmniSEC Omni-01 software. Before the GPC measurement, the polymer was cleaved from the clay by LiBr refluxing in THF for about $24 \mathrm{~h}$, followed by centrifugation and filtration through a filter. Differential scanning calorimetry (DSC) was performed on a Perkin-Elmer Diamond DSC with a heating rate of $20^{\circ} \mathrm{C} \mathrm{min}{ }^{-1}$

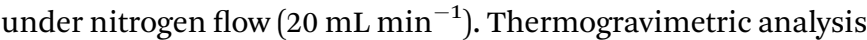
(TGA) was performed on a Perkin-Elmer Diamond TA/TGA with a heating rate of $10{ }^{\circ} \mathrm{C} \mathrm{min}^{-1}$ under nitrogen flow $(200 \mathrm{~mL}$ $\left.\min ^{-1}\right)$. The surface morphology was monitored with a FEI Quanta250 FEG scanning electron microscope (SEM). An accelerating voltage of $5.0 \mathrm{kV}$ was applied for each sample, and a spot size of 3 was used. X-ray diffraction (XRD) measurements were carried out with a Panalytical X'Pert Pro Materials Research Diffractometer with $\mathrm{CuK}_{\alpha}$ radiation $(\lambda=1.5406 \AA$ ). The XRD data were collected in a step scanning mode in the range from $5.0^{\circ}$ to $50^{\circ}$. The zeta potential of the synthesized nanocomposite samples was measured by using a Malvern Zetasizer Nano ZS. $1.0 \mathrm{~mL}$ sample was loaded into a cell and the zeta potential was measured simultaneously three times and in triplicate. Atomic force microscopy (AFM) measurements were conducted by using a Nanosurf flexAFM (Liestel, Switzerland).

\section{Cell culture on clay matrices}

A549 and HeLa cells were grown in the DMEM containing 10\% FCS and $1.0 \% \mathrm{P} / \mathrm{S}$. All cells were cultivated in a medium at $37{ }^{\circ} \mathrm{C}$ in a humidified environment with $5.0 \% \mathrm{CO}_{2}$. The cell seeding density and passage number used for both cell lines were 30000 cells per $\mathrm{mL}$ and 10 .

Cell adhesion on clay matrices was observed using a fluorescence microscope and proliferation studies using the MTT assay. ${ }^{28}$ MMT- $\left(\mathrm{CH}_{2} \mathrm{CH}_{2} \mathrm{OH}\right)_{2}, \mathrm{PCL} / \mathrm{MMT}-\left(\mathrm{CH}_{2} \mathrm{CH}_{2} \mathrm{OH}\right)_{2}$, PCL/ MMT- $\left(\mathrm{CH}_{2} \mathrm{CH}_{2} \mathrm{OH}\right)_{2}-\mathrm{FA}(5.0 \%$ FA) (NC-5) and PCL/MMT$\left(\mathrm{CH}_{2} \mathrm{CH}_{2} \mathrm{OH}\right)_{2}-\mathrm{FA}(8.0 \% \mathrm{FA})(\mathrm{NC}-8)$ were compared among themselves to observe the differences in their properties as cell culture materials. Therefore, $1.0 \mathrm{mg}$ of each clay mineral was suspended in $50 \mu \mathrm{L}$ THF and $950 \mu \mathrm{L}$ PBS, then $50 \mu \mathrm{L}$ of the suspension (per well) was added to 96 well tissue cultured 
polystyrene plates (TCPS) (Sarstedt). Plates were dried for $24 \mathrm{~h}$ at room temperature. Afterward, clay covered plates were sterilized under UV radiation for $3 \mathrm{~h}$ and used for cell culture experiments. In the proliferation assay, cells which were cultivated directly on TCPS without clay matrices were considered as negative control. Each trial was repeated 5 times. Cells were incubated for 1 h, 17 h, 24 h, 48 h, 72 h and 96 h. At the end of each cultivation time, cells were treated with $110 \mu \mathrm{L}, 10 \%$ MTT solution (5.0 $\mathrm{mg} \mathrm{mL}^{-1} \mathrm{PBS}$ ) per well plates, in the medium for $4 \mathrm{~h}$. Then, SDS solution $(100 \mu \mathrm{L}, 1.0 \mathrm{~g}$ SDS in $10 \mathrm{~mL} 0.01 \mathrm{M} \mathrm{HCl})$ was added and after $24 \mathrm{~h}$ incubation, UV-visible absorption was measured at $570 \mathrm{~nm}$ with $630 \mathrm{~nm}$ as the reference wavelength using a microplate reader (Bio-Tek Instruments, Inc., Winooski, VT, USA). Furthermore, each cell was stained with DAPI to visualize cell nuclei. For this aim, cell staining medium was removed and cells were washed once with $\mathrm{PBS}$, then, cells were treated with a DAPI solution $\left(1.0 \mathrm{mg} \mathrm{mL}^{-1}\right)$ for $15 \mathrm{~min}$ at $37^{\circ} \mathrm{C}$, then washed again with PBS several times. Fluorescence of the stained samples was monitored using an Olympus BX53F fluorescence microscope equipped with a CCD camera (Olympus DP72). For DAPI, a U-MWU excitation filter, BP330385 (exciter filter), and BA420 (barrier filter) were used.

Afterwards, the adhered cell density on the surfaces was calculated as cells per $\mathrm{mm}^{2}$ from the captured images which were taken from at least 4 or 5 different regions using HeLa and A549 cells after nuclei staining via ImageJ Software.

\section{Bright-field microscopy imaging}

To investigate the morphological alteration of adhered cells on different surfaces (NC-8, PCL/MMT- $\left.\left(\mathrm{CH}_{2} \mathrm{CH}_{2} \mathrm{OH}\right)_{2}\right)$ as well as TCPS as control, bright-field microscopy images were taken by using an Andor Revolution Confocal Laser Microscope (Olympus IX-71 fluorescence microscopy). Each sample (1.0 $\mathrm{mg} \mathrm{mL}^{-1}$ in 50 $\mu \mathrm{L}$ THF and $950 \mu \mathrm{L}$ PBS) was coated onto TCPS $\mu$-Dishes (Ibidi $\mathrm{GmbH}$, Germany) except control. After drying, UV sterilization was performed for $3 \mathrm{~h}$ and HeLa cells were grown for 3 days on the surfaces. Prior to bright-field imaging, cells were washed with PBS, then fixed using 4.0\% formaldehyde (dissolved in PBS) for $30 \mathrm{~min}$ and rinsed with PBS several times.

\section{Electrochemical measurements}

All electrochemical experiments were carried out on a Palmsens potantiostat (Palm Instruments, Houten, Netherlands). A three electrode system consists of an $\mathrm{Ag} / \mathrm{AgCl}$ reference electrode, a platinum electrode as the auxiliary electrode and a $3.0 \mathrm{~mm}$ diameter glassy carbon electrode (GCE) as the working electrode was used. Prior to measurements, the GCE was polished with alumina slurry followed by sonication in the $1: 1$ distilled water-ethanol mixture for $5 \mathrm{~min}$. After that, mirror like GCE surfaces were coated with $15 \mu \mathrm{L}$ of $1.0 \mathrm{mg} \mathrm{mL}{ }^{-1}$ clay samples (dissolved in $900 \mu \mathrm{L}$ PBS, pH 7.4 and $100 \mu \mathrm{L} \mathrm{THF}$ ) and $5.0 \mu \mathrm{L}$ of $1.0 \mathrm{mg} \mathrm{mL}{ }^{-1}$ BSA (in PBS buffer). Electrodes were allowed to dry for about $1 \mathrm{~h}$. Finally, an appropriate amount of cells in PBS was dropped onto the clay modified GCE surfaces and incubated for $2 \mathrm{~h}$ under ambient conditions. HeLa (folate positive) and A549 (folate negative) cell lines were applied during the experiments.
Cyclic voltammetry (CV) (between $-0.4 \mathrm{~V}$ and $0.6 \mathrm{~V}$ ) and differential pulse voltammetry (DPV) (between $-0.2 \mathrm{~V}$ and $0.6 \mathrm{~V}$ ) techniques were performed after each modification using $\left[\mathrm{Fe}(\mathrm{CN})_{6}\right]^{3-/ 4-}$ as a water soluble redox probe $(10 \mathrm{mM})$. Cell binding to the surface caused decreases in the response signals which were correlated with the cell loaded onto the surface. Differences between the current signals were calculated as follows:

$$
\Delta I=I_{\mathrm{o}}-I_{\mathrm{c}}
$$

where $I_{\mathrm{o}}$ is the mean current at zero cell concentration and $I_{\mathrm{c}}$ is the mean current at any concentration by after cell binding onto the clay covered surfaces.

\section{Statistical analysis}

All experiments were repeated 5 times. All data were expressed as average \pm SD (standard deviation) unless particularly outlined. A one-way analysis of variance (ANOVA) was performed with the Tukey test for multiple comparisons in statistical evaluation. The difference between two groups was considered to be significant when the $P$ value was less than 0.05 and highly significant when the $P$ value was less than 0.01 or 0.001 .

\section{Results and discussion}

\section{Synthesis and characterization of nanocomposites}

Folic acid (folate, FA), which is composed of a pterin ring, $p$-amino benzoic acid and glutamic acid moieties, has been used widely as a targeting ligand to deliver therapeutics to cancer cells because of its ability to react with the membraneanchored protein called FA receptor. Use of FA in targeting strategies is advantageous because it is nontoxic, non-immunogenic, inexpensive and stable. Conjugation of FA molecules with various nanoparticle types via polymer spacer units has been extensively investigated. ${ }^{29}$ In order to impart its existing advantages, initially, the FA salt was physically adsorbed at the edges and interlayers of commercially available Cloisite $30 \mathrm{~B}$ (a natural MMT clay fully modified with an organic surfactant containing two hydroxyl groups) in a manner similar to that described previously. These hydroxyl groups on the clay surface allowed the grafting of initiators and the growth of PCL chains from the clay surface, favoring the exfoliation of the platelets (Scheme 1).

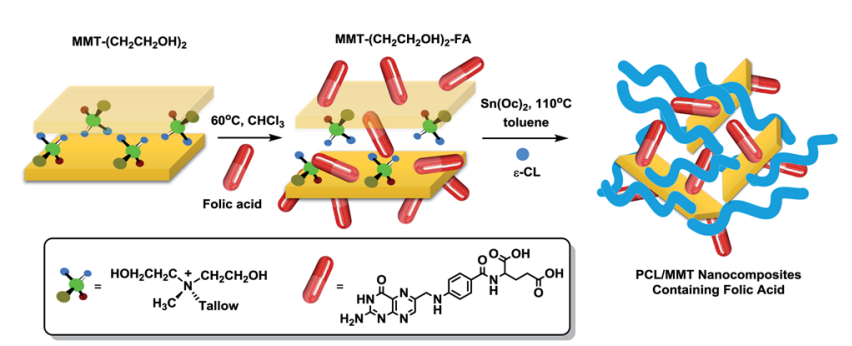

Scheme 1 Modification of MMT- $\left(\mathrm{CH}_{2} \mathrm{CH}_{2} \mathrm{OH}\right)_{2}$ with FA and synthesis of PCL/MMT nanocomposites containing FA by in situ ring-opening polymerization. 
FT-IR, XRD, and TGA techniques were used to characterize modification of the MMT clay with FA. As shown in Fig. 1, the bands of pure FA between 3600 and $3400 \mathrm{~cm}^{-1}$ are due to the hydroxyl $(\mathrm{OH})$ stretching bands of the glutamic acid moiety and the $\mathrm{NH}$ group of the pterin ring. It also exhibited a very strong absorption band at 1696, 1513 and $1485 \mathrm{~cm}^{-1}$ due to the stretching vibration of $(\mathrm{C}=\mathrm{O})$ and a characteristic absorption band of the phenyl and pterin rings. The pristine MMT- $\left(\mathrm{CH}_{2} \mathrm{CH}_{2} \mathrm{OH}\right)_{2}$ showed typically broad $\mathrm{O}-\mathrm{H}$ and $\mathrm{Si}-\mathrm{O}$ stretching bands at 3633 and $1010 \mathrm{~cm}^{-1}$. Besides these verifications for the MMT- $\left(\mathrm{CH}_{2} \mathrm{CH}_{2} \mathrm{OH}\right)_{2}$ clay, the spectra show all the characteristic groups of FA.

The modification of MMT- $\left(\mathrm{CH}_{2} \mathrm{CH}_{2} \mathrm{OH}\right)_{2}$ with FA was also investigated by XRD and TGA methods (Table 1, Fig. 2). The basal spacing $\left(d_{001}\right)$ of commercial and modified clay layers was found to be $1.84 \mathrm{~nm}$ and $1.90 \mathrm{~nm}$. The increment of interlayer spacing indicates an intercalated system with insertion of FA molecules into clay layers. The weight loss of MMT- $\left(\mathrm{CH}_{2} \mathrm{CH}_{2} \mathrm{OH}\right)_{2}$ and MMT- $\left(\mathrm{CH}_{2} \mathrm{CH}_{2} \mathrm{OH}\right)_{2}-\mathrm{FA}$ was found to be 20.3 and $41.3 \mathrm{wt} \%$ as a result of degradation of the organic content of commercial clays. Both XRD and TGA results confirmed that the FA molecules were successfully incorporated into the MMT interlayer.

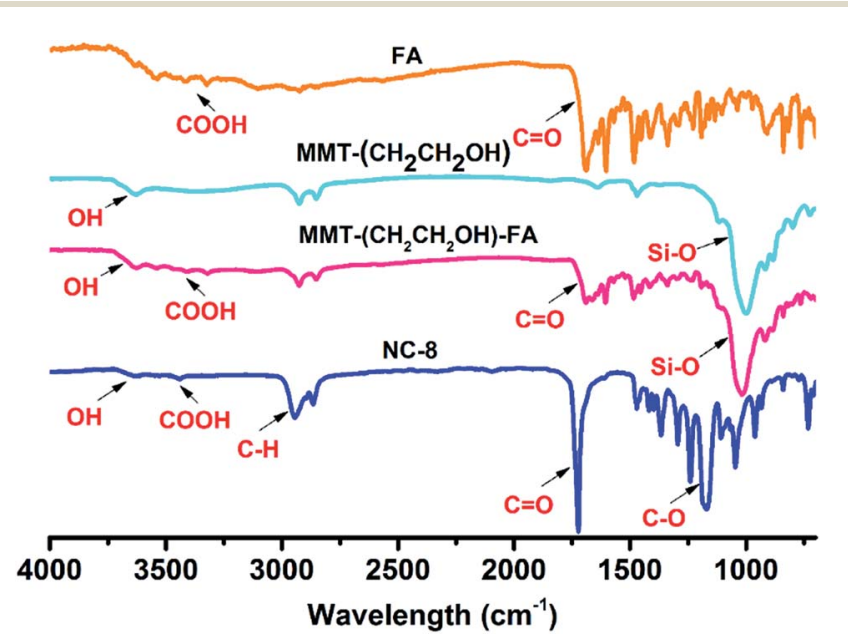

Fig. 1 FT-IR spectra of FA, MMT- $\left(\mathrm{CH}_{2} \mathrm{CH}_{2} \mathrm{OH}\right)_{2}, \mathrm{MMT}-\left(\mathrm{CH}_{2} \mathrm{CH}_{2}-\right.$ $\mathrm{OH})_{2}-\mathrm{FA}$, and the nanocomposite (NC-8).

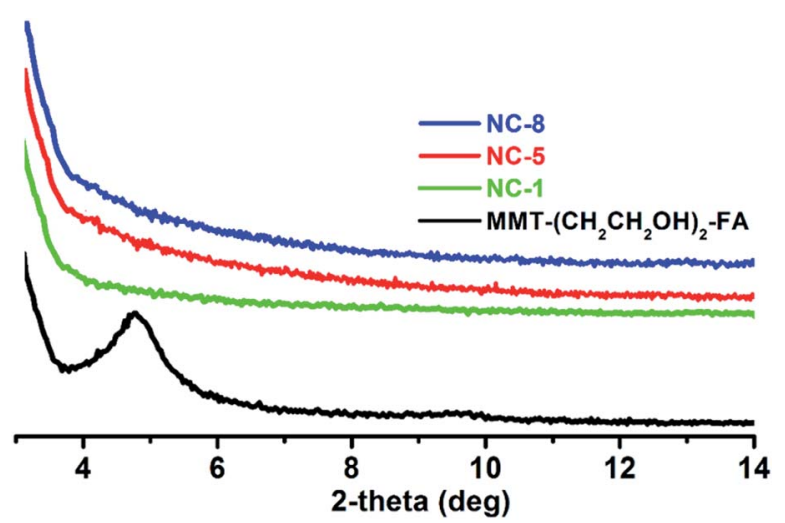

Fig. 2 X-ray diffractions of MMT- $\left(\mathrm{CH}_{2} \mathrm{CH}_{2} \mathrm{OH}\right)_{2}-\mathrm{FA}$ and the nanocomposites (NC-1, NC-5 and NC-8).
Ring opening polymerization of CL initiated by MMT$\left(\mathrm{CH}_{2} \mathrm{CH}_{2} \mathrm{OH}\right)_{2}-\mathrm{FA}$ (Scheme 1) was carried under various conditions typical for such polymerization reactions. The molecular weight results and reaction conditions are summarized in Table 1. With an increase in the nanoclay initiator amount, there was an increase in the polymerization rate, which results in the slightly higher conversion and lower molecular weights of the resulting polymers. The molecular weight distribution remained narrow (1.24-1.35) and unimodal during the polymerization. After the polymerization reactions, the XRD peak of MMT- $\left(\mathrm{CH}_{2} \mathrm{CH}_{2} \mathrm{OH}\right)_{2}-\mathrm{FA}$ disappeared in the X-ray diffraction pattern for all nanocomposite samples, which indicates the formation of exfoliated structures of the clay. The DSC thermograms, performed on nanocomposites, showed a slight reduction of the melting temperature with the increase of the clay content, suggesting that the degree of crystallinity was affected by the restricted mobility of the chains (Fig. 4). The thermal degradation temperatures of the nanocomposites with different organic clay loadings were very close to each other, and a slight increase with $10 \%$ and $50 \%$ weight loss temperatures was observed. Notably, the final char yields of the nanocomposites were increased from $1.2 \%$ to $8.5 \%$ by increasing clay loadings (Fig. 3).

The zeta potential of MMT- $\left(\mathrm{CH}_{2} \mathrm{CH}_{2} \mathrm{OH}\right)_{2}, \mathrm{PCL} / \mathrm{MMT}-\left(\mathrm{CH}_{2}-\right.$ $\left.\mathrm{CH}_{2} \mathrm{OH}\right)_{2}$ and NC-8 is given in Table 2. The surface potential of MMT- $\left(\mathrm{CH}_{2} \mathrm{CH}_{2} \mathrm{OH}\right)_{2}$ is found as highly negative. A less negative value was observed after modification with PCL and finally, FA intercalation caused a remarkable decrease in the surface potential of the nanocomposite. SEM micrographs of the nanocomposites are given in Fig. 5. The surface morphology of commercially available Cloisite $30 \mathrm{~B}$ and PCL/MMT- $\left(\mathrm{CH}_{2} \mathrm{CH}_{2} \mathrm{OH}\right)_{2}$ nanocomposites is shown in Fig. 5A and B, respectively. After treatment of the polymer with the clay, small clay aggregates are observed on the surface of nanocomposites (Fig. 5B). In addition, the SEM micrograph of the FA intercalated PCL/MMT- $\left(\mathrm{CH}_{2} \mathrm{CH}_{2} \mathrm{OH}\right)_{2}$ nanocomposite is given in Fig. 5C. It is clearly observed that the $\mathrm{PCL} / \mathrm{MMT}-\left(\mathrm{CH}_{2} \mathrm{CH}_{2} \mathrm{OH}\right)_{2}$ nanocomposite surface exhibits a rough surface after this modification step. Moreover, the surface morphologies with higher magnification $(20000 \times)$ are given in Fig. S1 (ESI†).

AFM was also used to evaluate the morphology of the nanocomposite surfaces as well. Fig. 6 shows AFM images of MMT- $\left(\mathrm{CH}_{2} \mathrm{CH}_{2} \mathrm{OH}\right)_{2}$, PCL/MMT- $\left(\mathrm{CH}_{2} \mathrm{CH}_{2} \mathrm{OH}\right)_{2}$ and NC-8. AFM images were obtained by depositing the samples on silicon wafer. Tapping mode was used during the measurements.

Additionally, the roughness of (MMT- $\left(\mathrm{CH}_{2} \mathrm{CH}_{2} \mathrm{OH}\right)_{2}, \mathrm{PCL} /$ MMT- $\left(\mathrm{CH}_{2} \mathrm{CH}_{2} \mathrm{OH}\right)_{2}$ and NC-8) was assessed by measuring the roughness parameters (Table 3 ).

Table 3 presents the roughness values of MMT- $\left(\mathrm{CH}_{2} \mathrm{CH}_{2} \mathrm{OH}\right)_{2}$, $\mathrm{PCL} / \mathrm{MMT}-\left(\mathrm{CH}_{2} \mathrm{CH}_{2} \mathrm{OH}\right)_{2}$ and NC-8 nanocomposites. They were measured in terms of roughness average $\left(S_{\mathrm{a}}\right)$, mean value $\left(S_{\mathrm{m}}\right)$, root-mean-square roughness $\left(S_{\mathrm{q}}\right)$, valley depth $\left(S_{\mathrm{v}}\right)$, peak height $\left(S_{\mathrm{p}}\right)$, and peak-valley height $\left(S_{\mathrm{y}}\right)$. The roughness values were calculated using integrated software for image analysis. Here, the peak-valley height is an estimate of $z$-values which is short or wide and tall or narrow. The average roughness $\left(S_{\mathrm{a}}\right)$ of $\mathrm{MMT}-\left(\mathrm{CH}_{2}-\right.$ $\left.\mathrm{CH}_{2} \mathrm{OH}\right)_{2}$, PCL/MMT- $\left(\mathrm{CH}_{2} \mathrm{CH}_{2} \mathrm{OH}\right)_{2}$ and NC-8 nanocomposites 
Table 1 Polymerization conditions and thermal properties of PCL/MMT- $\left(\mathrm{CH}_{2} \mathrm{CH}_{2} \mathrm{OH}\right)_{2}-\mathrm{FA}$ nanocomposites and their components

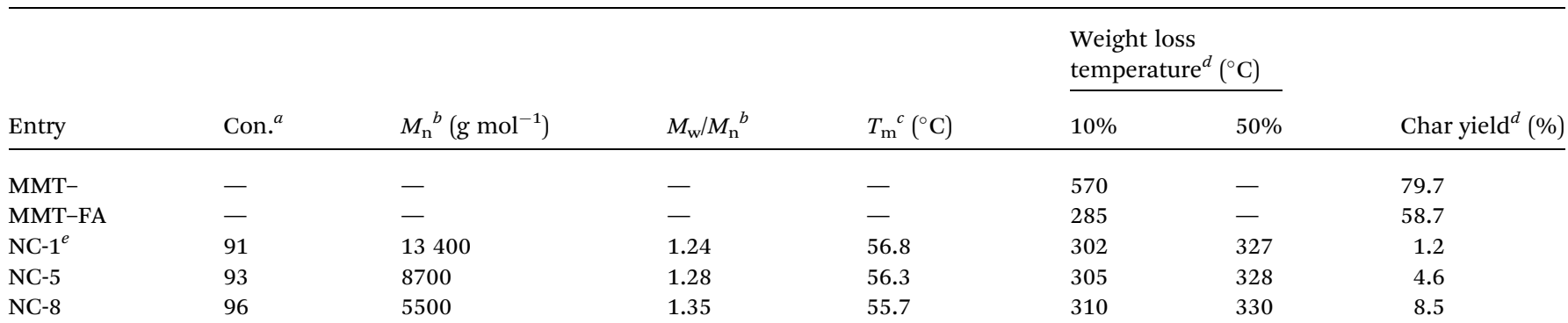

${ }^{a}$ Determined gravimetrically. ${ }^{b}$ Molecular weight and distribution were determined by gel permeation chromatography. ${ }^{c}$ Determined by DSC and analyses under a nitrogen flow at a heating rate of $10^{\circ} \mathrm{C} \mathrm{min}^{-1} .{ }^{d}$ Determined by TGA analysis under a nitrogen flow at a heating rate of $10^{\circ} \mathrm{C}$ min ${ }^{-1}$. ${ }^{e}$ The number indicates MMT-FA loadings.

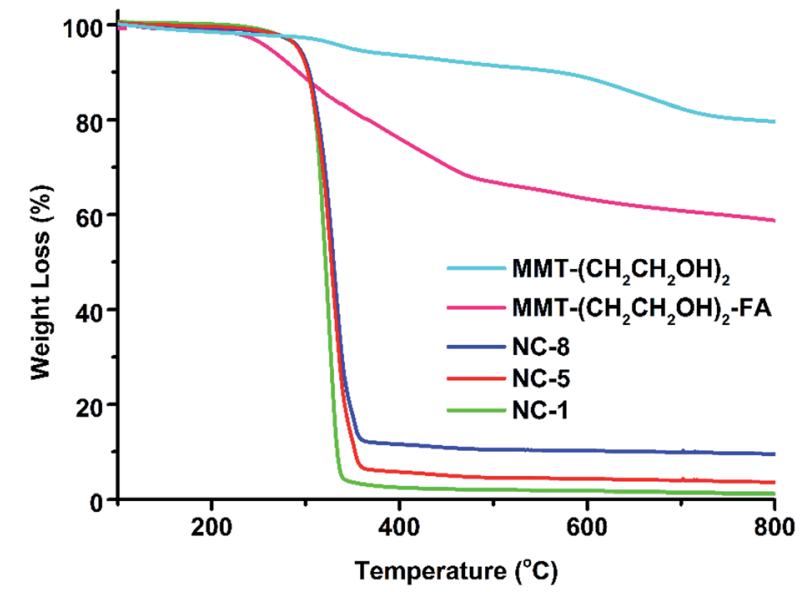

Fig. 3 TGA thermograms of MMT- $\left(\mathrm{CH}_{2} \mathrm{CH}_{2} \mathrm{OH}\right)_{2}, \mathrm{MMT}-\left(\mathrm{CH}_{2} \mathrm{CH}_{2}-\right.$ $\mathrm{OH})_{2}-\mathrm{FA}$ and the nanocomposites (NC-1, NC-5 and NC-8).

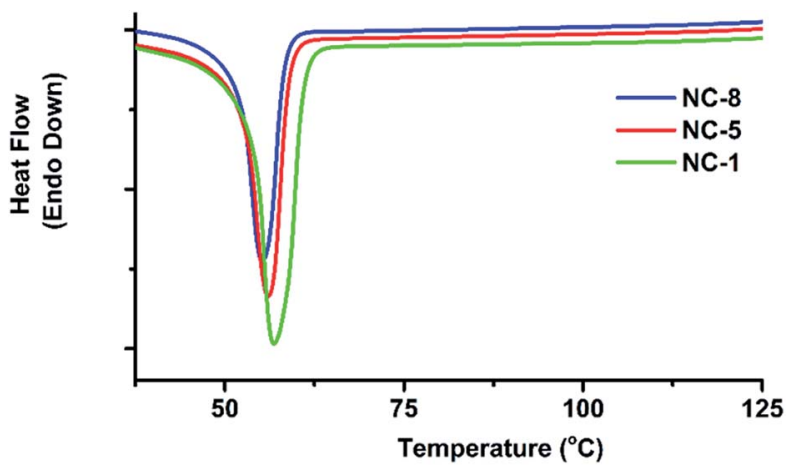

Fig. 4 DSC traces of the nanocomposites (NC-1, NC-5 and NC-8).

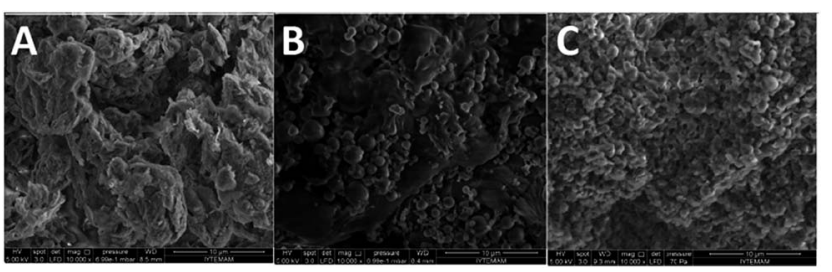

Fig. 5 SEM images of MMT- $\left(\mathrm{CH}_{2} \mathrm{CH}_{2} \mathrm{OH}\right)_{2}(\mathrm{~A}), \mathrm{PCL} / \mathrm{MMT}-\left(\mathrm{CH}_{2} \mathrm{CH}_{2} \mathrm{OH}\right)_{2}$ (B) and NC-8 (C) with $10000 \times$ magnification.

was $37.0 \mathrm{~nm}, 23.0 \mathrm{~nm}, 29.0 \mathrm{~nm}$, respectively. All values were obtained with $1 \times 1 \mu \mathrm{m}$ scan area. The AFM results also support the SEM images. Here, the surface roughness of PCL/MMT$\left(\mathrm{CH}_{2} \mathrm{CH}_{2} \mathrm{OH}\right)_{2}$ increases with the addition of FA.

\section{Cell proliferation}

The flexibility, biocompatibility, biodegradability and mechanical stability of the nanocomposites are very advantageous allowing their use in various biomedical applications. These features are important in the design of implants and drug delivery systems, biosensors, in vitro diagnostics and cell culture matrices. Enhanced cell adhesion and proliferation were observed on the intercalated structure of MMT-gelatinchitosan for the stromal stem cells. ${ }^{22}$ Lewkowitz-Shpuntoff et al. used other nanocomposites made from ethylene vinyl acetate and Cloisite and reported clay dependent growth of human dermal fibroblasts on the polymer nanocomposite surfaces. ${ }^{30}$ Recently, MMT was modified with $\mathrm{N}$-(2-hydroxy)propyl-3-trimethylammonium chitosan chloride and human bone marrow mesenchymal stem cells were used to evaluate cell growth on this matrix. ${ }^{31}$ Besides, poly(glycolic acid), PCL, poly(lactic acid) and these copolymers are very promising scaffolds for tissue

Table 2 Zeta potential values

\begin{tabular}{|c|c|c|c|c|}
\hline MMT- $\left(\mathrm{CH}_{2} \mathrm{CH}_{2} \mathrm{OH}\right)_{2}$ & -28.10 & -28.10 & 100 & 3.22 \\
\hline $\mathrm{PCL} / \mathrm{MMT}-\left(\mathrm{CH}_{2} \mathrm{CH}_{2} \mathrm{OH}\right)_{2}$ & -24.40 & -24.40 & 100 & 4.72 \\
\hline
\end{tabular}



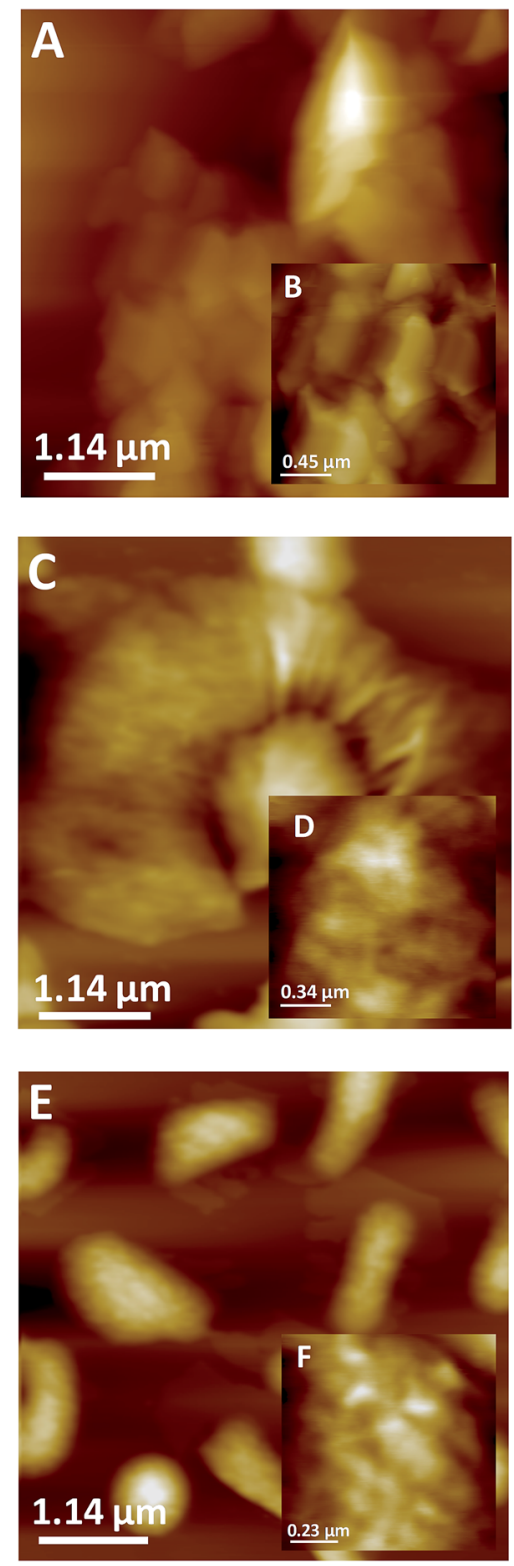

Fig. 6 AFM images of MMT- $\left(\mathrm{CH}_{2} \mathrm{CH}_{2} \mathrm{OH}\right)_{2}(\mathrm{~A}), \mathrm{PCL} / \mathrm{MMT}-\left(\mathrm{CH}_{2} \mathrm{CH}_{2} \mathrm{OH}\right)_{2}$ (C), and NC-8 (E) nanocomposites. A, $\mathrm{C}$ and $\mathrm{E}$ images are $5 \times 5 \mu \mathrm{m}$ and the inset $B$ is $2 \times 2 \mu \mathrm{m}, D$ is $1.5 \times 1.5 \mu \mathrm{m}$ and $F$ is $1 \times 1 \mu \mathrm{m}$.

engineering studies because of their good biocompatibility and degradation. ${ }^{32-34}$ Therefore, PCL has been considered as a potential substrate for drug delivery systems, ${ }^{35}$ scaffolds for supporting fibroblast and osteoblast growth ${ }^{36,37}$ and as a matrix for the cell growth. ${ }^{38,39}$

In the present work, MMT- $\left(\mathrm{CH}_{2} \mathrm{CH}_{2} \mathrm{OH}\right)_{2}$ was modified with PCL to enhance biocompatibility and with FA to target folate receptor (FR) rich cancer cells. After characterization, clay suspensions were dried on the surface of 96 well plates. FR overexpressed HeLa and FR poor A549 cells were used for testing the cell adhesion properties of the pristine clay and modified clay matrices. ${ }^{9}$ Proliferation behaviors of HeLa and A549 cells on the surface of clay layers were investigated with MTT assay. A higher amount of the cell was observed on PCL/ MMT- $\left(\mathrm{CH}_{2} \mathrm{CH}_{2} \mathrm{OH}\right)_{2}$ for both cell lines (in Fig. 7A and B). These are expected results due to the effect of introduction of biocompatible PCL to MMT- $\left(\mathrm{CH}_{2} \mathrm{CH}_{2} \mathrm{OH}\right)_{2}$ into the structure.
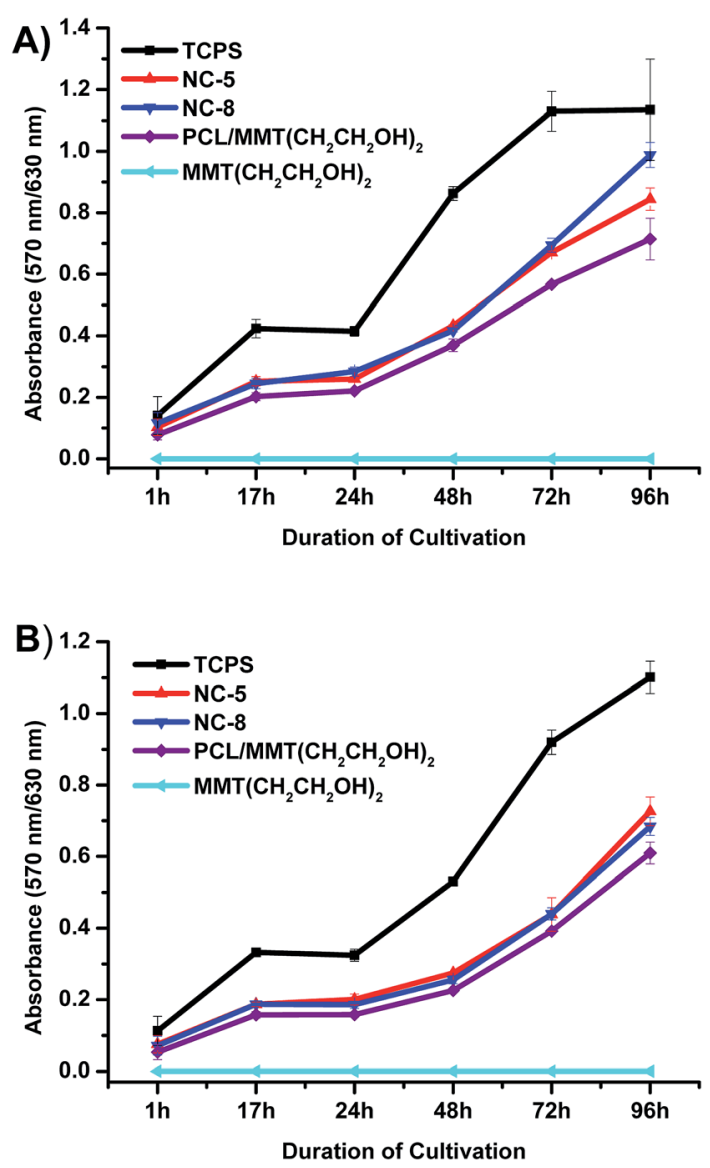

Fig. 7 Proliferation behaviour of HeLa (A) and $\mathrm{A} 549$ (B) on the surface of MMT- $\left(\mathrm{CH}_{2} \mathrm{CH}_{2} \mathrm{OH}\right)_{2}, \mathrm{PCL} / \mathrm{MMT}-\left(\mathrm{CH}_{2} \mathrm{CH}_{2} \mathrm{OH}\right)_{2}, \mathrm{NC}-5, \mathrm{NC}-8$ and positive control cells cultivated on the 96 -well plate surface.

Table 3 The roughness measurements of the clay, polymer clay nanocomposite, and polymer clay folic acid nanocomposite (roughness average $\left(S_{a}\right)$, mean value $\left(S_{m}\right)$, root-mean-square roughness $\left(S_{q}\right)$, valley depth $\left(S_{v}\right)$, peak height $\left(S_{p}\right)$, and peak-valley height $\left(S_{y}\right)$ )

\begin{tabular}{llllrr}
\hline Sample & $S_{\mathrm{a}}(\mathrm{nm})$ & $S_{\mathrm{m}}(\mathrm{nm})$ & $S_{\mathrm{q}}(\mathrm{nm})$ & $S_{\mathrm{v}}(\mathrm{nm})$ & $S_{\mathrm{p}}(\mathrm{nm})$ \\
\hline MMT- $\left(\mathrm{CH}_{2} \mathrm{CH}_{2} \mathrm{OH}\right)_{2}$ & 37.0 & 34.5 & 43.5 & -28.0 & 82.0 \\
PCL/MMT- $\left(\mathrm{CH}_{2} \mathrm{CH}_{2} \mathrm{OH}\right)_{2}$ & 23.0 & 23.5 & 23.5 & 9.0 & 32.0 \\
NC-8 & 29.0 & 29.0 & 29.5 & 10.2 & 39.0
\end{tabular}


Fig. 7A demonstrates that the cell amount of HeLa on NC-8 increases compared to the control cells which are grown directly on TCPS well plates. Also, better cell proliferation on NC-8 was observed in comparison with NC-5 $(p<0.05)$. We assume that the main reason for the better proliferation behaviour of HeLa on NC-8 with respect to NC-5 is due to the presence of more FA in the clay structure. On the other side no significant difference was observed on the proliferation behaviour of A549 cells on PCL/MMT- $\left(\mathrm{CH}_{2} \mathrm{CH}_{2} \mathrm{OH}\right)_{2}$, NC-5 and NC-8 (Fig. 7B). After $48 \mathrm{~h}$, both HeLa and A549 cells were proliferated on nanocomposite surfaces between time intervals, significantly $(p<0.05$ for $48-72$ $h$ and 72-96 h).

Furthermore, DAPI was used to visualize adhered cells on the matrices via cell nuclei staining. The inefficient adhesion of both cell lines on MMT- $\left(\mathrm{CH}_{2} \mathrm{CH}_{2} \mathrm{OH}\right)_{2}$ is observed after $72 \mathrm{~h}$ cultivation time as shown in Fig. 8A and $\mathrm{B}$. The cell amount for both cell lines on PCL/MMT- $\left(\mathrm{CH}_{2} \mathrm{CH}_{2} \mathrm{OH}\right)_{2}$ was higher comparing to MMT- $\left(\mathrm{CH}_{2} \mathrm{CH}_{2} \mathrm{OH}\right)_{2}$. In the case of A549, there is no any significant difference in proliferation features between PCL/MMT- $\left(\mathrm{CH}_{2} \mathrm{CH}_{2} \mathrm{OH}\right)_{2}$, NC-5 and NC-8. But on NC-5 and especially on NC-8 FR, positive HeLa cells grew favorably. All fluorescence microscopic investigations are congruent with the proliferation results.

To obtain more informative data from the fluorescent images, further analysis based on cell density (cells per $\mathrm{mm}^{2}$ ) was accomplished using the ImageJ Software. Fig. 9 illustrates the cell density analysis of both A549 and HeLa cells upon varying modified surfaces. It appears that both NC-5 and NC-8 surfaces have created a significant difference between HeLa and A549 cells $(p<0.01$ for NC-5 and $p<0.001$ for NC-8). Furthermore, the increase of FA amount in the nanocomposite structures caused the selective cell adhesion compared to MMT- $\left(\mathrm{CH}_{2} \mathrm{CH}_{2} \mathrm{OH}\right)_{2}$ and PCL/MMT- $\left(\mathrm{CH}_{2} \mathrm{CH}_{2} \mathrm{OH}\right)_{2}$ surfaces, despite the fact that A549 cells grew better on the PCL/MMT- $\left(\mathrm{CH}_{2} \mathrm{CH}_{2} \mathrm{OH}\right)_{2}$ surface $(p<0.01)$. However, there is no considerable change among NC-1, NC-5 and NC-8 surfaces.

\section{Bright-field microscopy imaging}

HeLa cells that were grown on PCL/MMT- $\left(\mathrm{CH}_{2} \mathrm{CH}_{2} \mathrm{OH}\right)_{2}$, NC-8 and control groups were visualized by bright-field microscopy to understand if there is any considerable change on the morphology of the cells (Fig. S2, in the ESI $\dagger$ ). It can be stated that the NC-8 coated surface did not affect the general morphology of the HeLa cell when compared to the control groups which are cultivated on TCPS.

\section{Electrochemical studies}

Electrochemical techniques are considered as good alternative to design biosensors for label-free detection of cells. ${ }^{40}$ Detection principles for cell analysis via electrochemical platforms are mainly based on creation of a self-assembled monolayer on the electrode. ${ }^{41,42}$ These surfaces could be adapted properly to 'Lab-ona-Chip' or microfluidic based systems. ${ }^{43}$ On the other hand, decision on the immobilization matrix affects the selectivity of the biosensor for the analysis, significantly. Herein, after the successful cell adhesion experiments, NC-8 was applied to create a

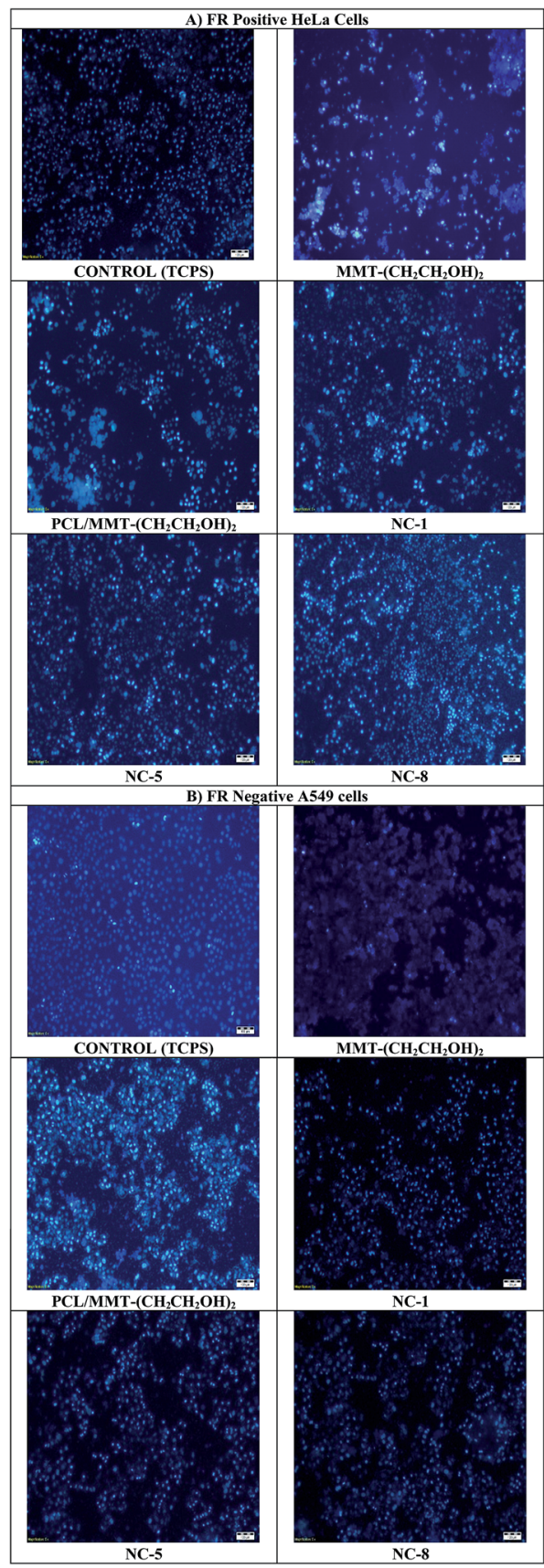

Fig. 8 Fluorescence images of DAPI stained HeLa (A) and A549 cells (B) cultivated on TCPS, MMT- $\left(\mathrm{CH}_{2} \mathrm{CH}_{2} \mathrm{OH}\right)_{2}, \mathrm{PCL} / \mathrm{MMT}-\left(\mathrm{CH}_{2} \mathrm{CH}_{2} \mathrm{OH}\right)_{2}$, NC-1, NC-5 and NC-8 after 72 hours.

novel selective platform for the cultivation of folate positive HeLa cells. CV and DPV experiments were performed using ferricyanide as a redox mediator. Fig. 10A shows the oxidation and reduction peaks of bare and MMT- $\left(\mathrm{CH}_{2} \mathrm{CH}_{2} \mathrm{OH}\right)_{2}, \mathrm{PCL} / \mathrm{MMT}-\left(\mathrm{CH}_{2} \mathrm{CH}_{2} \mathrm{OH}\right)_{2}$ and NC-8 modified GCE surfaces, sequentially. The cationic nature of the MMT- $\left(\mathrm{CH}_{2} \mathrm{CH}_{2} \mathrm{OH}\right)_{2}$ clay exhibited sharper and higher redox peaks compared to the bare GCE due to the stronger attraction of negatively charged $\left[\mathrm{Fe}(\mathrm{CN})_{6}\right]^{3-/ 4-}$ on the surface. DPV graphs also showed the similar response characteristics. A dramatic decrease in the peak current was observed when the PCL 


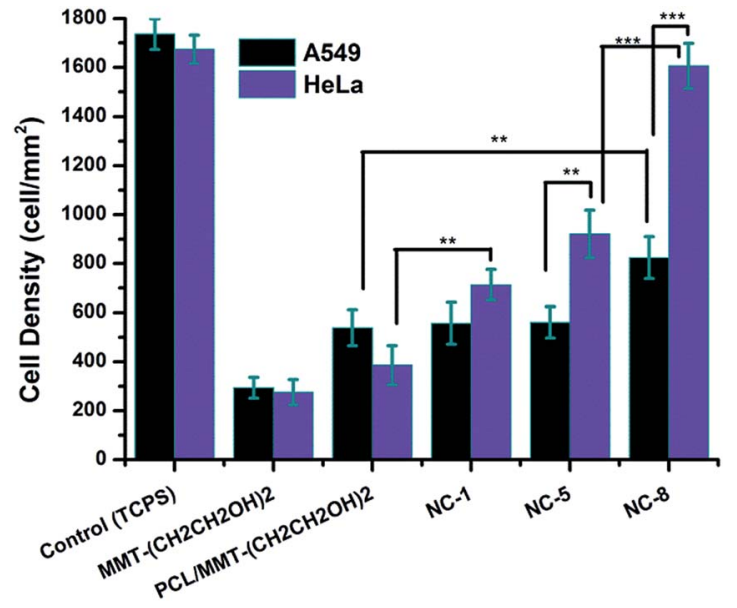

Fig. 9 Cell density analysis using the DAPI stained fluorescent cell images after $72 \mathrm{~h}$ cultivation via Image J software.
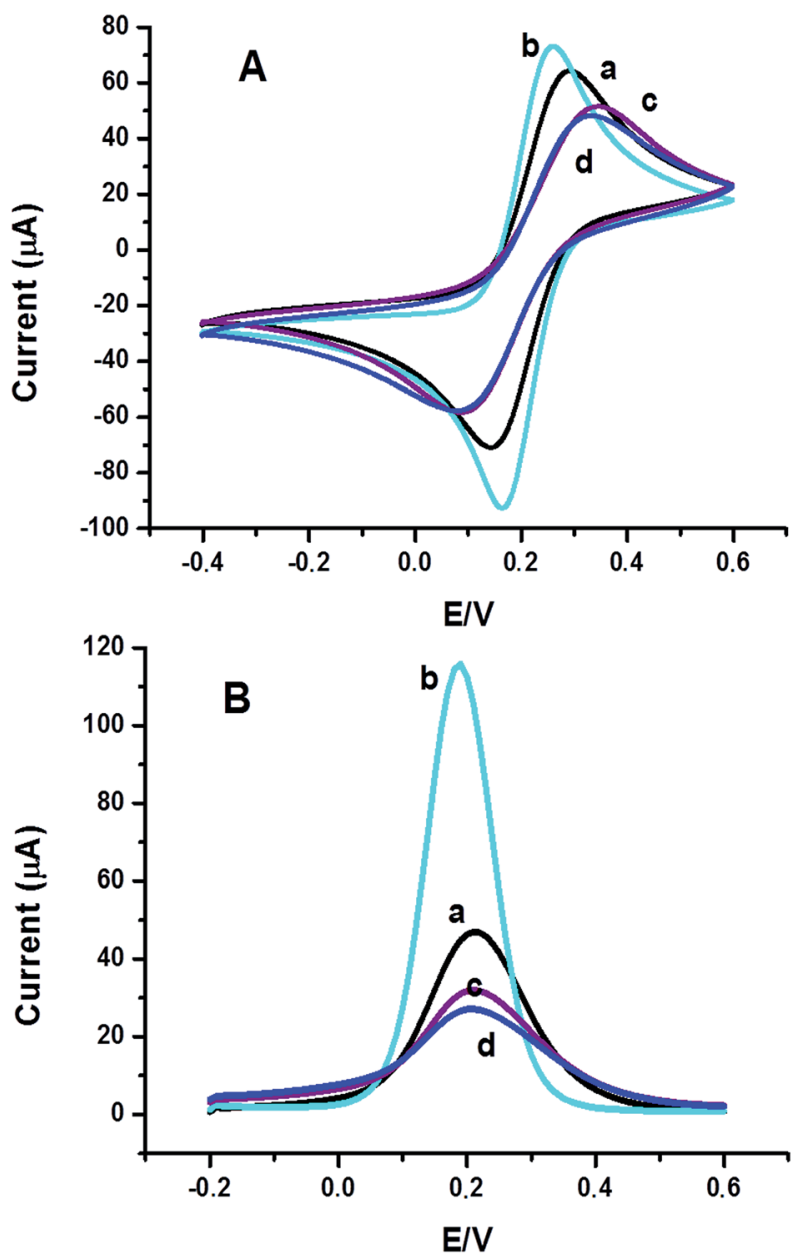

Fig. 10 Electrochemical behaviour of the bare GCE (a), MMT$\left(\mathrm{CH}_{2} \mathrm{CH}_{2} \mathrm{OH}\right)_{2}$ (b), PCL/MMT- $\left(\mathrm{CH}_{2} \mathrm{CH}_{2} \mathrm{OH}\right)_{2}$ (c) and NC-8 (d) using cyclic voltammetry (A) and differential pulse voltammetry (B) in phosphate buffer saline, $\mathrm{pH} 7.4$ with the presence of $10 \mathrm{mM}[\mathrm{Fe}(\mathrm{CN})$ $6]^{3-14-}$ at $50 \mathrm{mV} \mathrm{s}^{-1}$. intercalated clay was covered on the electrode surface due to the rather inefficient electron transfer properties. Similar electrochemical characteristics were also obtained with NC-8 (Fig. 10). As can be seen from Fig. 10B, the peak current values were found to be $54.35 \mu \mathrm{A}\left(E_{\mathrm{p}}=0.2 \mathrm{~V}\right)$ for the bare GCE, $114.4 \mu \mathrm{A}\left(E_{\mathrm{p}}=0.18 \mathrm{~V}\right)$ for MMT- $\left(\mathrm{CH}_{2} \mathrm{CH}_{2} \mathrm{OH}\right)_{2}, 31.8 \mu \mathrm{A}\left(E_{\mathrm{p}}=0.2 \mathrm{~V}\right)$ for PCL/MMT- $\left(\mathrm{CH}_{2}-\right.$ $\left.\mathrm{CH}_{2} \mathrm{OH}\right)_{2}$ and $22.6 \mu \mathrm{A}\left(E_{\mathrm{p}}=0.19 \mathrm{~V}\right)$ for NC-8, respectively.

Afterwards, cell sensing studies were carried out via $\mathrm{CV}$ and DPV techniques. Cyclic voltammograms of the bare GCE (Fig. 10A(a)), GCE/NC-8 (Fig. 10A(b)), A549 $\left(1 \times 10^{4}\right.$ cells)/NC-8/ GCE (Fig. $11 \mathrm{~A}(\mathrm{c}))$ and HeLa $\left(1 \times 10^{4}\right.$ cells $) / \mathrm{NC}-8 / \mathrm{GCE}$ (Fig. $11 \mathrm{~A}(\mathrm{~d})$ ) were in an agreement with each other in the presence of $10 \mathrm{mM}[\mathrm{Fe}(\mathrm{CN}) 6]^{3-/ 4-}$ at $50 \mathrm{mV} \mathrm{s}^{-1}$. Redox peaks of CVs are as follows; $64.47 \mu \mathrm{A}\left(E_{\mathrm{pc}}=0.28 \mathrm{~V}\right)$ for the GCE, $48.08 \mu \mathrm{A}$ $\left(E_{\mathrm{pc}}=0.32 \mathrm{~V}\right)$ for GCE/NC-8, 33.7 $\mu \mathrm{A}\left(E_{\mathrm{pc}}=0.45 \mathrm{~V}\right)$ for GCE/NC8/A549 and $18.72 \mu \mathrm{A}\left(E_{\mathrm{pc}}=0.52 \mathrm{~V}\right)$. A drop in the peak currents and shifting in the peak potentials ( $E_{\mathrm{pc}}$ (cathodic) and $E_{\mathrm{pa}}$ (anodic)) showed successful cell binding onto the NC-8 surface. On the other hand, FR overexpressed HeLa cells display better adherence than FR negative A549 cells as well. To prove
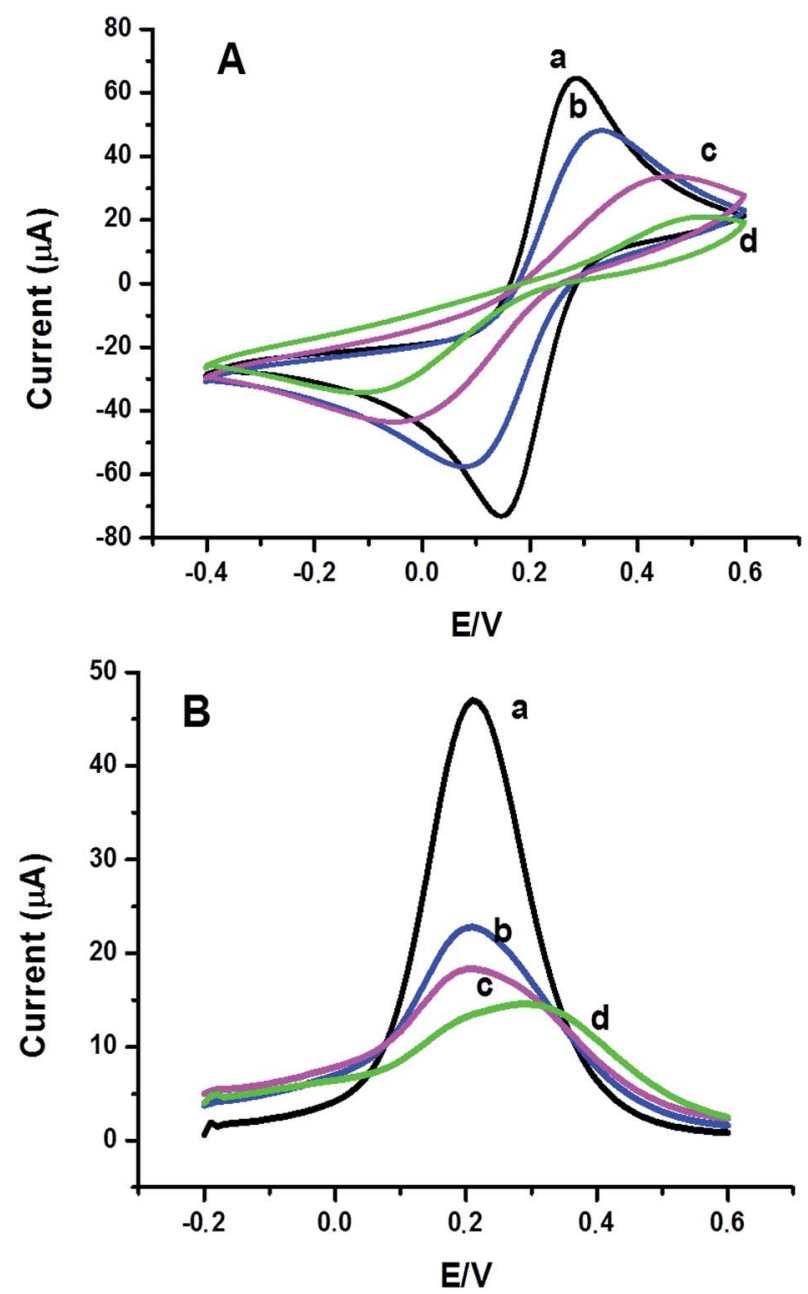

Fig. 11 (A) Cyclic voltammograms (B) differential pulse voltammograms of the bare GCE (a), GCE/NC-8 (b), GCE/NC-8/10 4 A549 cells (c) and GCE/NC-8/10 4 HeLa cells (d) in phosphate buffer saline, $\mathrm{pH} 7.4$ with the presence of $10 \mathrm{mM}[\mathrm{Fe}(\mathrm{CN}) 6]^{3-14-}$ at $50 \mathrm{mV} \mathrm{s}^{-1}$. 
the cell capture of NC-8; both DPV and CV techniques were used as previous studies in which the affinity type sensors were reported. ${ }^{44}$ After treatment of the NC-8 modified electrode with the HeLa cells, a calibration curve was obtained by the decrease in the current signals $(\Delta I)$ depending on the cell amount within DPV measurements. The linear relationship is defined by the equation of $y=4.466 x-8.285\left(R^{2}=0.999, y\right.$ is $\Delta I(\mu \mathrm{A})$ and $x$ is the logarithm of the cell amount) between $1 \times 10^{2}$ and $1 \times 10^{4}$ cells per mL. As shown in Fig. 11A and B, treatment of cells caused a decrease in the current response. To control the selectivity of the NC-8/GCE surface, the same amount of A549 and HeLa cells $\left(1 \times 10^{4}\right)$ was compared. Fig. 11B displays the DPV responses of FR negative A549 $(\Delta I=4.8 \mu \mathrm{A})$ and FR positive HeLa cells $(\Delta I=9.54 \mu \mathrm{A})$. Moreover, within the addition of HeLa cells onto the NC-8 surface, a shift in the peak potentials was observed due to the strong adherence between HeLa cells and FA groups. Hence it can be claimed that NC-8 is an appropriate platform for the selective and label free cell detection for further cell sensing approaches.

\section{Conclusions}

In conclusion, a promising material that allows selective cell adhesion and proliferation was synthesized and characterized as a cell culture and biosensing platform. Besides, it provides an efficient way for the detection of FR positive cells via electrochemical transduction as well as optical monitoring. This principle could be adapted for targeted detection of the other cells where different proteins are overexpressed in the case of different diseases. The advantage of this strategy resides in the fast and easy surface modification with the targeting ligands.

\section{Acknowledgements}

Ibidi $\mathrm{GmbH}$ is acknowledged for their supports to the cell culture studies.

\section{Notes and references}

1 B. Lepoittevin, M. Devalckenaere, N. Pantoustier, M. Alexandre, D. Kubies, C. Calberg, R. Jerome and P. Dubois, Polymer, 2002, 43, 4017-4023.

2 M. A. Tasdelen, Eur. Polym. J., 2011, 47, 937-941.

3 M. A. Tasdelen, J. Kreutzer and Y. Yagci, Macromol. Chem. Phys., 2010, 211, 279-285.

4 J. Chen, H. Wang, W. Luo, J. Xiang, L. Zhang and B. Sun, Colloid Polym. Sci., 2010, 288, 173-179.

5 Y.-S. Ye, Y.-C. Yen, C.-C. Cheng, Y.-J. Syu, Y.-J. Huang and F.-C. Chang, Polymer, 2010, 51, 430-436.

6 H.-W. Cui and S.-W. Kuo, RSC Adv., 2012, 2, 12148-12152.

7 M. A. Tasdelen, W. Van Camp, E. Goethals, P. Dubois, F. Du Prez and Y. Yagci, Macromolecules, 2008, 41, 6035-6040.

8 M. Aydin, M. A. Tasdelen, T. Uyar, S. Jockusch, N. J. Turro and Y. Yagci, J. Polym. Sci., Part A: Polym. Chem., 2013, 51, 1024-1028.
9 B. Lepoittevin, N. Pantoustier, M. Devalckenaere, M. Alexandre, D. Kubies, C. Calberg, R. Jerome and P. Dubois, Macromolecules, 2002, 35, 8385-8390.

10 A. Oral, M. A. Tasdelen, A. L. Demirel and Y. Yagci, J. Polym. Sci., Part A: Polym. Chem., 2009, 47, 5328-5335.

11 A. Oral, M. A. Tasdelen, A. L. Demirel and Y. Yagci, Polymer, 2009, 50, 3905-3910.

12 H. Akat, M. A. Tasdelen, F. Du Prez and Y. Yagci, Eur. Polym. J., 2008, 44, 1949-1954.

13 M. Aydin, M. A. Tasdelen, T. Uyar and Y. Yagci, J. Polym. Sci., Part A: Polym. Chem., 2013, 51, 5257-5262.

14 C. Dizman, S. Ates, T. Uyar, M. A. Tasdelen, L. Torun and Y. Yagci, Macromol. Mater. Eng., 2011, 296, 1101-1106.

15 K. D. Demir, M. A. Tasdelen, T. Uyar, A. W. Kawaguchi, A. Sudo, T. Endo and Y. Yagci, J. Polym. Sci., Part A: Polym. Chem., 2011, 49, 4213-4220.

16 C. Altinkok, T. Uyar, M. A. Tasdelen and Y. Yagci, J. Polym. Sci., Part A: Polym. Chem., 2011, 49, 3658-3663.

17 Z. Yenice, M. A. Tasdelen, A. Oral, C. Guler and Y. Yagci, J. Polym. Sci., Part A: Polym. Chem., 2009, 47, 2190-2197.

18 A. Nese, S. Sen, M. A. Tasdelen, N. Nugay and Y. Yagci, Macromol. Chem. Phys., 2006, 207, 820-826.

19 A. K. Gaharwar, P. J. Schexnailder, B. P. Kline and G. Schmidt, Acta Biomater., 2011, 7, 568-577.

20 K. Haraguchi, T. Takehisa and M. Ebato, Biomacromolecules, 2006, 7, 3267-3275.

21 G. Ozkoc, S. Kemaloglu and M. Quaedflieg, Polym. Compos., 2010, 31, 674-683.

22 H. Zhuang, J. P. Zheng, H. Gao and K. D. Yao, J. Mater. Sci.: Mater. Med., 2007, 18, 951-957.

23 F. Grinnell, Trends Cell Biol., 2003, 13, 264-269.

24 A. Abbott, Nature, 2003, 424, 870-872.

25 C. S. Chen, M. Mrksich, S. Huang, G. M. Whitesides and D. E. Ingber, Science, 1997, 276, 1425-1428.

26 R. McBeath, D. M. Pirone, C. M. Nelson, K. Bhadriraju and C. S. Chen, Dev. Cell, 2004, 6, 483-495.

27 R. Bongartz, D. Ag, M. Seleci, J.-G. Walter, E. E. Yalcinkaya, D. O. Demirkol, F. Stahl, S. Timur and T. Scheper, J. Mater. Chem. B, 2013, 1, 522-528.

28 D. Ag, R. Bongartz, L. E. Dogan, M. Seleci, J.-G. Walter, D. O. Demirkol, F. Stahl, S. Ozcelik, S. Timur and T. Scheper, Colloids Surf., B, 2014, 114, 96-103.

29 K. Kaaki, K. Hervé-Aubert, M. Chiper, A. Shkilnyy, M. Soucé, R. Benoit, A. Paillard, P. Dubois, M.-L. Saboungi and I. Chourpa, Langmuir, 2011, 28, 1496-1505.

$30 \mathrm{H}$. M. Lewkowitz-Shpuntoff, M. C. Wen, A. Singh, N. Brenner, R. Gambino, N. Pernodet, R. Isseroff, M. Rafailovich and J. Sokolov, Biomaterials, 2009, 30, 8-18.

31 M. Aliabadi, R. Dastjerdi and K. Kabiri, BioMed Res. Int., 2013, 749240.

32 S. Y. Lee, J. H. Oh, J. C. Kim, Y. H. Kim, S. H. Kim and J. W. Choi, Biomaterials, 2003, 24, 5049-5059.

33 N. Isogai, S. Asamura, T. Higashi, Y. Ikada, S. Morita, J. Hillyer, R. Jacquet and W. J. Landis, Tissue Eng., 2004, 10, 673-687.

34 K. W. Ng and D. W. Hutmacher, Biomaterials, 2006, 27, 45914598. 
35 Z. K. Zhong and X. Z. S. Sun, Polymer, 2001, 42, 6961-6969. 36 D. W. Hutmacher, T. Schantz, I. Zein, K. W. Ng, S. H. Teoh and K. C. Tan, J. Biomed. Mater. Res., 2001, 55, 203-216.

37 M. C. Serrano, R. Pagani, M. Vallet-Regi, J. Pena, A. Ramila, I. Izquierdo and M. T. Portoles, Biomaterials, 2004, 25, 56035611.

38 M. Gumusderelioglu, S. Dalkiranoglu, R. S. T. Aydin and S. Cakmak, J. Biomed. Mater. Res., Part A, 2011, 98, 461-472. 39 S. Y. Kim, J. Appl. Polym. Sci., 2011, 121, 1921-1929.
40 S. Andreescu and O. A. Sadik, Methods, 2005, 37, 84-93.

41 R. Wang, J. Di, J. Ma and Z. Ma, Electrochim. Acta, 2012, 61, 179-184.

42 J. Zhao, L. Zhu, C. Guo, T. Gao, X. Zhu and G. Li, Biosens. Bioelectron., 2013, 49, 329-333.

43 M. Moscovici, A. Bhimji and S. O. Kelley, Lab Chip, 2013, 13, 940-946.

44 W. Cheng, L. Ding, J. Lei, S. Ding and H. Ju, Anal. Chem., 2008, 80, 3867-3872. 